\title{
In vitro propagation of five Alocasia species
}

\author{
Arvind Bhatt ${ }^{1}$; Christine Stanly ${ }^{2}$; Chan Lai Keng ${ }^{2}$ \\ ${ }^{1}$ School of Life Sciences, University of KwaZulu-Natal, Westville Campus, Private Bag X54001, Durban, 4000, South Africa; \\ drbhatt79@gmail.com; ${ }^{2}$ School of Biological Sciences, Universiti Sains Malaysia, 11800 Penang, Malaysia
}

\begin{abstract}
The influence of cytokinin, N6-benzyladenine, on shoot proliferation of five Alocasia species (A. amazonica, A. cuprea, A. robusta, $A$. longiloba and $A$. chaii) was investigated. In vitro propagation of these species was established using shoot tip explants. Murashige \& Skoog (MS) medium supplemented with different concentrations of BA (N6-benzyladenine) ranging from 0, 2, 5, 10 $\mathrm{mg} / \mathrm{L}$ was then used to establish the optimum medium for shoot proliferation for all the species. MS medium supplemented with 2.0 $\mathrm{mg} / \mathrm{L}$ BA was optimum for the shoot proliferation. All the tested species showed varying results for shoot number and shoot height. A comparison between agar-gelled medium and shake flask system using liquid medium was carried out to evaluate the shoot growth and proliferation for all the tested species. For A. amazonica, A. cuprea, $A$. robusta and $A$. longiloba, shake flask system using liquid medium of the same constituents stimulated more shoot proliferation as compared to agar-gelled medium. However, for $A$. chaii there was no significant difference. All the in vitro plantlets with well developed roots and leaves were successfully acclimatized with more than $90 \%$ survival rate.
\end{abstract}

Keywords: Alocasia amazonica, A. cuprea, A. robusta, A. longiloba, A. chaii, culture medium, acclimatization.

\section{RESUMO}

Propagação in vitro de cinco espécies de Alocasia

Pesquisou-se a influência da citocinina, N6-benziladenina, na proliferação de gemas de cinco espécies de Alocasia (A. amazonica, A. cuprea, A. robusta, A. Longiloba e $A$. chaii). A propagação in vitro dessas espécies foi estabelecida utilizando explantes de ápices caulinares. O meio Murashige \& Skoog (MS), adicionado de diferentes concentrações $(0,2,5,10 \mathrm{mg} / \mathrm{L})$ de BA (N6-benziladenina), foi utilizado para estabelecer o meio ideal para a proliferação de ramos para todas as espécies. Verificou-se que o meio MS suplementado com 2,0 mg/L de BA foi ideal para a proliferação de ramos. Todas as espécies avaliadas mostraram resultados variáveis em termos de número e altura dos brotos. Comparou-se os sistemas agar-gel e frascos de agitação em meio líquido, quanto ao crescimento de brotos e à proliferação de todas as espécies testadas. Para A. amazonica, A. cuprea, $A$. robusta e $A$. longiloba, o sistema de frascos em meio líquido dos mesmos constituintes estimulou a proliferação de brotos em comparação ao meio agar-gel. No entanto, para $A$. chaii não houve diferença significativa. Todas plântulas obtidas in vitro, bem enraizadas e com folhas bem desenvolvidas, foram aclimatizadas com sucesso obtendo-se mais de $90 \%$ de taxa de sobrevivência.

Palavras-chave: Alocasia amazonica, A. cuprea, A. robusta, A. longiloba, A. chaii, meio de cultura, aclimatação.

\section{(Recebido para publicação em 6 de abril de 2012; aceito em 10 de abril de 2013)} (Received on April 6, 2012; accepted on April 10, 2013)

\begin{abstract}
Aloc locasia, one of the most morphologically diverse genera in the family Araceae, comprises about 100 species (Boyce, 2008). Plants of this genus are rhizomatous or bulbous perennials with large heart-shaped leaves. Alocasia species, due to their foliar charm, patterns of leaf variegation and texture, as well as tolerance to limited sunlight are very popular ornamentals among plant collectors and landscape gardeners. Many Alocasia species are endemic to Borneo. For instance, Alocasia cuprea is endemic to the Sabah state of Malaysia (Boyce et al., 2002). According to the IUCN red list of threatened species $A$. atropurpurea, $A$. sanderiana and $A$. sinuata are critically endangered (IUCN, 2010). Alocasia species are conventionally propagated
\end{abstract}

through seeds and corms. However, conventional methods of propagation are time consuming and restrict the mass propagation of Alocasia species (Jo et al., 2008). Hence it is necessary to develop efficient and economically viable micro-propagation protocols to ensure conservation and meet the commercial demand for Alocasia species. Through in vitro propagation, disease-free plants can be produced throughout the year and can be used for germplasm conservation (Sanatombi \& Sharma, 2008).

Although the commercial demand for Alocasia species is high, few reports exist on their in vitro propagation and associated protocols. This limited amount of scientific literature deals mainly with Alocasia micholitziana,
A. longiloba, A. amazonica and A. cuculata (Thao et al., 2003; Adelberg \& Toler, 2004; Chan \& Chong, 2010). However, there are no reports available on the in vitro micropropagation of Alocasia robusta, A. cuprea and A. chaii. This paper outlines an efficient in vitro propagation protocol for five species of Alocasia: A. amazonica, A. cuprea, A. robusta, $A$. longiloba, and $A$. chaii. The specific objectives of this study were (i) to investigate the effect of BA on the shoot proliferation and (ii) to compare the efficacy of liquid medium and agargelled medium on the proliferation rates of these species.

\section{MATERIAL AND METHODS}

Plant materials and culture 
conditions - The Alocasia species used in this study were obtained from Malesiana Tropicals Sdn. BhD., Kuching, Sarawak, Malaysia and planted in the greenhouse of School of Biological Sciences, Universiti Sains Malaysia, Penang, Malaysia. Sterilization procedure was carried out according to Chan et al. (2010). The rhizomes, with emerging buds, were excised from the plants and, to remove adhering dirt and soil, were washed under running water for about 30 minutes. These buds were surface-sterilized with $20 \%$ Clorox $^{\circledR}$ (commercial bleach solution containing $5.3 \%$ sodium hypochlorite) to which a few drops of Tween 20, a wetting agent, was added. This was followed by washing the explants three times with sterile distilled water. The buds were again surface-sterilized for 10 minutes using $10 \%$ Clorox $^{\circledR}$ added with a few drops of Tween 20. This was followed by rinsing three times in sterile distilled water. The bud explants were then inoculated into $350 \mathrm{~mL}$ glass jars containing basal Murashige \& Skoog (1962) (MS) medium supplemented with $100 \mathrm{mg} / \mathrm{L}$ myo-inositol, $30 \mathrm{~g} / \mathrm{L}$ sucrose and $7.5 \mathrm{~g} / \mathrm{L}$ agar for 10 days. The $\mathrm{pH}$ of the medium was adjusted to 5.8 with $\mathrm{KOH}$ before the addition of agar. The medium was autoclaved at $121^{\circ} \mathrm{C}$ and $1.06 \mathrm{~kg} / \mathrm{cm}^{2}$ for 11 minutes. All the cultures were placed in a culture room maintained at $23 \pm 2^{\circ} \mathrm{C}$ with continuous fluorescent lighting of 32.5 $\mu \mathrm{mol} / \mathrm{m}^{2} / \mathrm{s}$. To get enough explants for further experiments, the aseptic in vitro plants were subcultured every 4 weeks on culture medium with the same constituents.

Effect of BA (N6-benzyladenine) on multiple shoot formation in Alocasia species - Using a completely randomized block design, the $1 \mathrm{~cm}$ long aseptic shoot tip explants were inoculated onto MS medium supplemented with 0 , 2.0, 5.0 and $10.0 \mathrm{mg} / \mathrm{L} \mathrm{BA}$ in $350 \mathrm{~mL}$ glass jar for a period of 4 weeks. The number of multiple shoots formed, shoot height, number of roots, and root length produced by each explant was recorded. Three bud explants were inoculated into each glass jar and six glass jars were used for each concentration of BA ( $\mathrm{n}=$ 18). The experiment was carried out two times. The data were analyzed by two-way ANOVA and means were compared by Tukey's test using SPSS v. 12.0 statistical program.

Comparison between agargelled and liquid cultures on growth proliferation - Since it was found that MS medium supplemented with $2.0 \mathrm{mg} / \mathrm{L} \mathrm{BA}$ was optimum for shoot proliferation for all the species, it was hence chosen for subsequent experiments. One centimeter long shoot tip explants were cultured into 350 $\mathrm{mL}$ glass jars containing agar-gelled proliferation medium (MS medium supplemented with $2.0 \mathrm{mg} / \mathrm{L} \mathrm{BA}$ ). For liquid culture, shoot explants were inoculated into $250 \mathrm{~mL}$ conical flasks containing $25 \mathrm{~mL}$ of liquid proliferation medium (MS medium supplemented with $2.0 \mathrm{mg} / \mathrm{L} \mathrm{BA}$ without the addition of agar) and placed on a rotary shaker (Lab Companion, Sk-600) at 120 rpm. Three explants were inoculated into each glass jar and six samples were used for each type of medium ( $n=$ 18) and the experiment was carried out twice for each species. All the cultures were placed in a culture room maintained at $23 \pm 2^{\circ} \mathrm{C}$ with continuous fluorescent lighting of $32.5 \mu \mathrm{mol} / \mathrm{m}^{2} / \mathrm{s}$. The experiment was repeated twice. The number of multiple shoots formed, number of roots, shoot height and root length produced by each explant for each species was recorded after four weeks of culture period. These data were analyzed by Student t-test to compare the means using SPSS v. 12.0.

Acclimatization of in vitro plantlets - The rooted in vitro plantlets with a shoot height of $\geq 2 \mathrm{~cm}$ were selected for acclimatization. Shoots were removed from the culture vessel, washed with tap water and planted into trays containing organic soil and sand in the ratio $1: 1$ and kept under shaded greenhouse for 4 weeks. The plantlets were exposed to a relative humidity of $80-90 \%$, temperature $\left(28 \pm 2^{\circ} \mathrm{C}\right.$ during day time and $24 \pm 2{ }^{\circ} \mathrm{C}$ during night time) and watered twice a day during the period of acclimatization. Fifty in vitro plantlets were used for acclimatization procedure. After four weeks, the number of surviving plantlets and the mean shoot height were recorded. The experiment was repeated twice.

\section{RESULTS AND DISCUSSION}

The surface sterilization of the rhizome buds resulted in $50 \%$ of the aseptic explants. New leaves and roots started to emerge from the explants after four weeks of culture. The aseptic shoots of all species were transferred to MS medium supplemented with different concentrations of $\mathrm{BA}(0.0,2.0,5.0$ and $10.0 \mathrm{mg} / \mathrm{L}$ ) to evaluate the rate of shoot proliferation. Results indicated that MS medium supplemented with $2.0 \mathrm{mg} / \mathrm{L} \mathrm{BA}$ was most suitable in

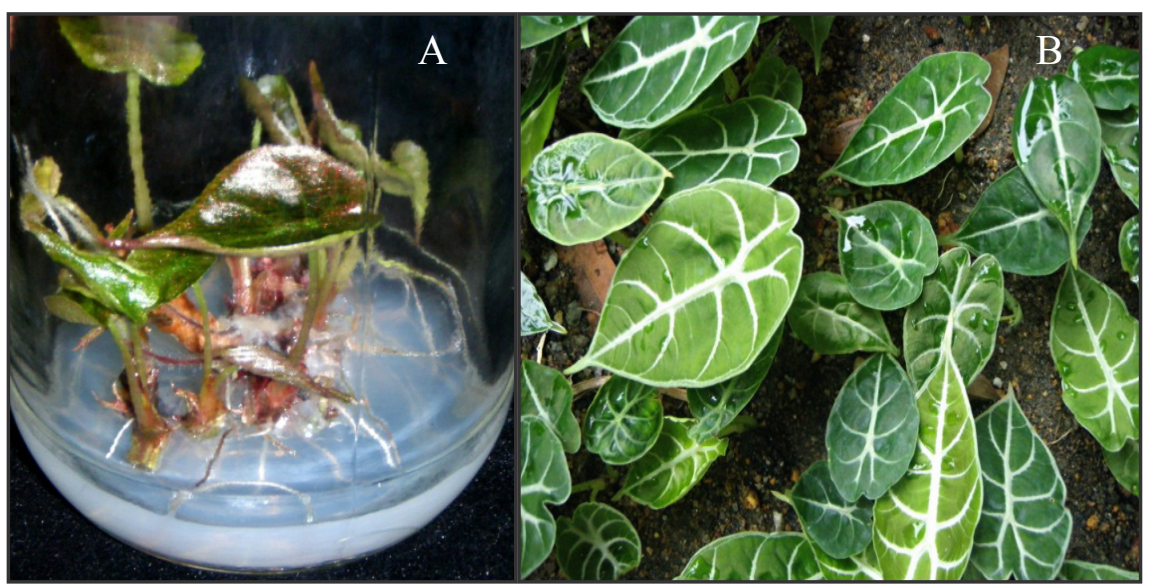

Figure 1. (A) In vitro shoots of A. cuprea cultured on MS medium supplemented with 2.0 $\mathrm{mg} / \mathrm{L}$ showing multiple shoot formation. (B) Acclimatized planlets of $A$. longiloba (brotos in vitro de $A$. cuprea cultivados em meio MS suplementado com $2,0 \mathrm{mg} / \mathrm{L}$ mostrando a formação de brotos múltiplos. (B) plântulas climatizadas de A. longiloba). Malaysia, USM, 2010. 


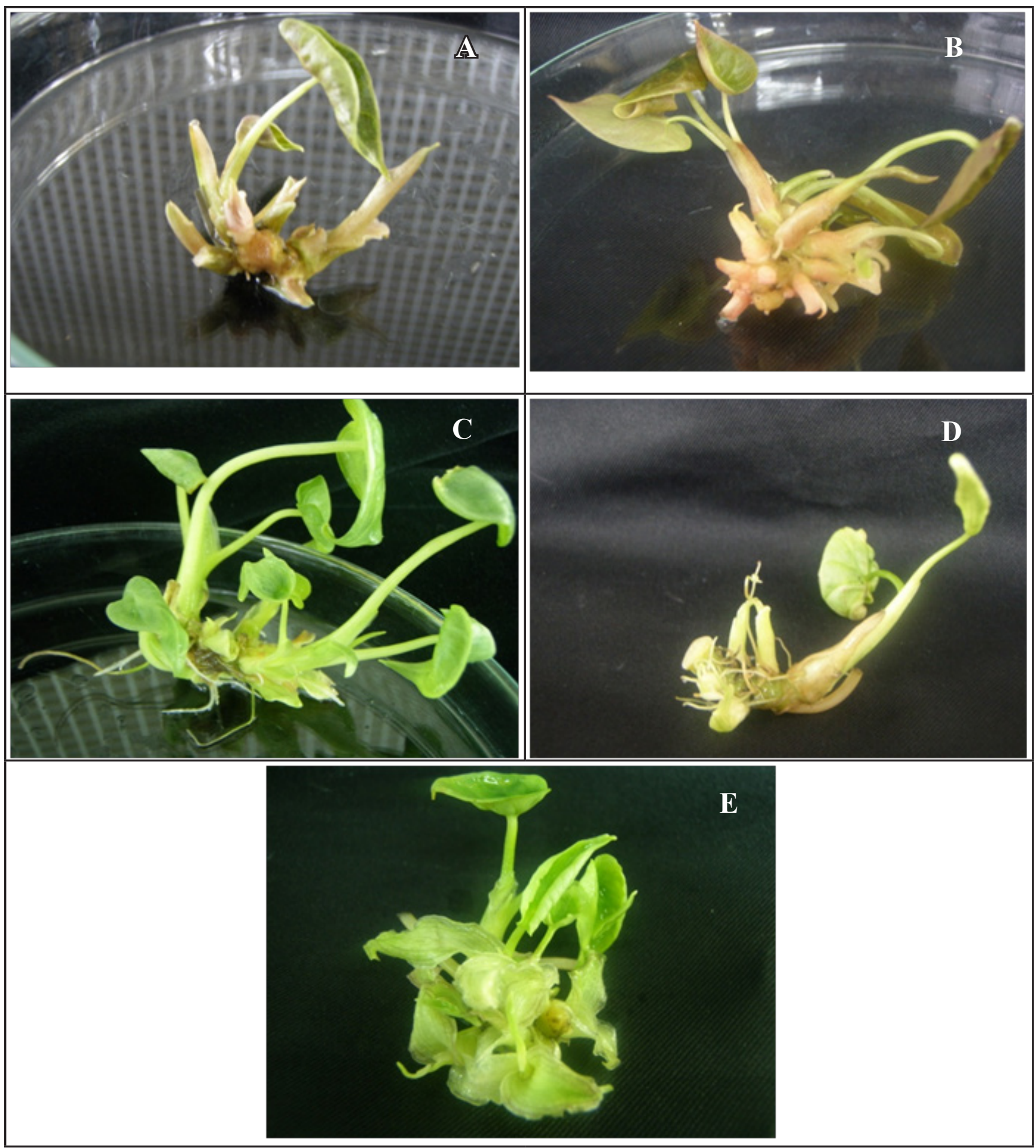

Figure 2. In vitro shoots of $A$. amazonica (A), A. cuprea (B), A. robusta (C), A. longiloba (D) and A. chaii (E) in liquid MS medium supplemented with $2.0 \mathrm{mg} / \mathrm{L}$ BA (brotos in vitro de $A$. amazonica (A), A. cuprea (B), A. robusta (C), A. longiloba (D) e A. chaii (E) em meio MS líquido suplementado com 2,0 mg/L de BA). Malaysia, USM, 2010.

producing the highest number of shoots among all the tested species. Among the five species, A. amazonica and $A$. cuprea produced the highest number of shoots $(5.3 \pm 1.7$ and $5.2 \pm 0.4$ per explant) (Figure 1A). Jo et al. (2008) reported the micropropagation of $A$.
Amazonica using different plant growth regulators. They found out that shoot explants of $A$. amazonica cultured in $2.27 \mu \mathrm{M}$ Thidiazuron (TDZ) produced an average of 5.1 shoots per explant. Similar results were also reported by Thao et al. (2003) whereby shoot cultures of A. micholitziana 'Green velvet', A. cuculata and A. Amazonica also produced on average 5 shoots per explant when cultured on $5 \mathrm{mg} / \mathrm{L}$ BA. The shoot tip explants of $A$. longiloba and $A$. chaii produced $4.6 \pm 0.6$ and $4.2 \pm 0.4$ shoots per explant respectively 
Table 1. Effect of BA (N6-benzyladenine) on the growth and proliferation of shoots and roots of five Alocasia species (efeito de BA (N6benziladenina) sobre o crescimento e proliferação de brotos e raízes de cinco species de Alocasia). Malaysia, USM, 2010.

\begin{tabular}{|c|c|c|c|c|c|}
\hline Species name & $\begin{array}{c}\text { Concentration of } \\
\text { BA }(\mathrm{mg} / \mathrm{L})\end{array}$ & $\begin{array}{l}\text { Shoots per ex- } \\
\text { plant } \pm \operatorname{s.d}\left(n^{0}\right)\end{array}$ & $\begin{array}{l}\text { Shoot height } \\
(\mathrm{cm}) \pm \text { s.d }\end{array}$ & $\begin{array}{l}\text { Roots per ex- } \\
\text { plant } \pm \text { s.d }\left(n^{0}\right)\end{array}$ & $\begin{array}{l}\text { Root length } \\
(\mathrm{cm}) \pm \text { s.d }\end{array}$ \\
\hline \multirow{4}{*}{ A. amazonica } & 0 & $1.4 \pm 0.5 \mathrm{a}$ & $3.2 \pm 0.3 \mathrm{a}$ & $3.6 \pm 0.5 \mathrm{~b}$ & $1.2 \pm 0.1 \mathrm{c}$ \\
\hline & 2 & $5.3 \pm 1.7 \mathrm{~b}$ & $3.9 \pm 0.1 \mathrm{a}$ & $3.3 \pm 0.3 \mathrm{~b}$ & $0.5 \pm 0.1 \mathrm{~b}$ \\
\hline & 5 & $6.8 \pm 1.4 \mathrm{~b}$ & $3.8 \pm 0.1 \mathrm{a}$ & $0.0 \pm 0.0 \mathrm{a}$ & $0.0 \pm 0.0 \mathrm{a}$ \\
\hline & 10 & $5.2 \pm 0.5 \mathrm{~b}$ & $3.7 \pm 0.5 \mathrm{a}$ & $0.0 \pm 0.0 \mathrm{a}$ & $0.0 \pm 0.0 \mathrm{a}$ \\
\hline \multirow{4}{*}{ A. cuprea } & 0 & $1.0 \pm 0.0 \mathrm{a}$ & $4.3 \pm 0.2 \mathrm{ab}$ & $3.0 \pm 0.6 \mathrm{~b}$ & $1.5 \pm 0.1 \mathrm{c}$ \\
\hline & 2 & $5.2 \pm 0.4 \mathrm{~b}$ & $4.7 \pm 0.4 \mathrm{~b}$ & $3.7 \pm 1.2 \mathrm{~b}$ & $1.2 \pm 0.0 \mathrm{~b}$ \\
\hline & 5 & $4.8 \pm 1.4 \mathrm{~b}$ & $4.0 \pm 0.2 \mathrm{a}$ & $0.0 \pm 0.0 \mathrm{a}$ & $0.0 \pm 0.0 \mathrm{a}$ \\
\hline & 10 & $3.5 \pm 0.4 \mathrm{~b}$ & $4.3 \pm 0.1 \mathrm{a}$ & $0.0 \pm 0.0 \mathrm{a}$ & $0.0 \pm 0.0 \mathrm{a}$ \\
\hline \multirow{4}{*}{ A. robusta } & 0 & $1.2 \pm 0.4 \mathrm{a}$ & $4.2 \pm 0.3 \mathrm{a}$ & $2.8 \pm 0.2 b$ & $1.5 \pm 0.1 \mathrm{c}$ \\
\hline & 2 & $3.4 \pm 1.0 \mathrm{~b}$ & $4.4 \pm 0.2 \mathrm{a}$ & $2.7 \pm 0.6 \mathrm{~b}$ & $0.3 \pm 0.0 \mathrm{~b}$ \\
\hline & 5 & $2.8 \pm 0.4 \mathrm{~b}$ & $4.1 \pm 0.1 \mathrm{a}$ & $0.0 \pm 0.0 \mathrm{a}$ & $0.0 \pm 0.0 \mathrm{a}$ \\
\hline & 10 & $2.3 \pm 0.7 \mathrm{ab}$ & $4.3 \pm 0.2 \mathrm{a}$ & $0.0 \pm 0.0 \mathrm{a}$ & $0.0 \pm 0.0 \mathrm{a}$ \\
\hline \multirow{4}{*}{ A. longiloba } & 0 & $1.2 \pm 0.4 \mathrm{a}$ & $4.9 \pm 0.2 b$ & $4.3 \pm 0.6 \mathrm{c}$ & $1.7 \pm 0.2 \mathrm{c}$ \\
\hline & 2 & $4.6 \pm 0.6 \mathrm{~b}$ & $4.9 \pm 0.7 \mathrm{~b}$ & $3.1 \pm 0.4 \mathrm{~b}$ & $0.5 \pm 0.2 b$ \\
\hline & 5 & $4.5 \pm 0.7 \mathrm{~b}$ & $4.0 \pm 0.0 \mathrm{a}$ & $0.0 \pm 0.0 \mathrm{a}$ & $0.0 \pm 0.0 \mathrm{a}$ \\
\hline & 10 & $3.0 \pm 0.9 \mathrm{~b}$ & $3.6 \pm 0.3 \mathrm{a}$ & $0.0 \pm 0.0 \mathrm{a}$ & $0.0 \pm 0.0 \mathrm{a}$ \\
\hline \multirow{4}{*}{ A. chaii } & 0 & $1.1 \pm 0.3 \mathrm{a}$ & $5.2 \pm 0.3 \mathrm{ab}$ & $6.3 \pm 0.6 b$ & $1.9 \pm 0.2 b$ \\
\hline & 2 & $4.2 \pm 0.4 \mathrm{c}$ & $5.3 \pm 0.1 \mathrm{ab}$ & $5.7 \pm 0.6 \mathrm{~b}$ & $1.8 \pm 0.1 \mathrm{~b}$ \\
\hline & 5 & $3.5 \pm 0.4 \mathrm{~b}$ & $4.3 \pm 0.8 \mathrm{ab}$ & $0.0 \pm 0.0 \mathrm{a}$ & $0.0 \pm 0.0 \mathrm{a}$ \\
\hline & 10 & $4.6 \pm 0.2 \mathrm{c}$ & $3.2 \pm 0.8 \mathrm{a}$ & $0.0 \pm 0.0 \mathrm{a}$ & $0.0 \pm 0.0 \mathrm{a}$ \\
\hline
\end{tabular}

Mean values \pm s.d followed by same letter within the column for each species are not significantly different (Tukey test, $\mathrm{p} \leq 0.05)$ [valores médios \pm s.d seguidos por mesma letra na coluna, para cada espécie não são significativamente diferentes pelo teste de Tukey $(\mathrm{p} \leq 0,05)]$.

Table 2. Effect of medium (MS $+2.0 \mathrm{mg} / \mathrm{L} \mathrm{BA}$ ) type on the growth and proliferation rates of five Alocasia species (efeito do tipo do meio (MS + 2,0 mg/L BA) sobre o crescimento e as taxas de proliferação de cinco especies de Alocasia). Malaysia, USM, 2010.

\begin{tabular}{|c|c|c|c|c|c|}
\hline Species name & Type of medium & $\begin{array}{c}\text { Shoots per } \\
\text { explant } \pm \text { S.d }\left(n^{0}\right)\end{array}$ & $\begin{array}{l}\text { Shoot height } \\
(\mathrm{cm}) \pm \text { s.d }\end{array}$ & $\begin{array}{c}\text { Roots per } \\
\text { explant } \pm \text { s.d }\left(n^{0}\right)\end{array}$ & $\begin{array}{l}\text { Root length } \\
(\mathrm{cm}) \pm \text { s.d }\end{array}$ \\
\hline \multirow{2}{*}{ A.amazonica } & Agar-gelled & $5.3 \pm 1.7 \mathrm{a}$ & $3.9 \pm 0.1 \mathrm{a}$ & $3.3 \pm 0.3 \mathrm{a}$ & $0.4 \pm 0.1 \mathrm{a}$ \\
\hline & Shake flask & $8.2 \pm 0.2 b$ & $5.5 \pm 0.3 \mathrm{~b}$ & $3.4 \pm 0.2 \mathrm{a}$ & $1.3 \pm 0.1 \mathrm{~b}$ \\
\hline \multirow{2}{*}{ A. cuprea } & Agar-gelled & $5.2 \pm 0.4 \mathrm{a}$ & $4.7 \pm 0.4 \mathrm{a}$ & $3.0 \pm 0.9 \mathrm{a}$ & $1.2 \pm 0.0 \mathrm{a}$ \\
\hline & Shake flask & $8.7 \pm 1.2 \mathrm{~b}$ & $6.1 \pm 0.2 \mathrm{~b}$ & $5.5 \pm 0.7 \mathrm{~b}$ & $1.5 \pm 0.2 \mathrm{a}$ \\
\hline \multirow{2}{*}{ A. robusta } & Agar-gelled & $3.4 \pm 1.0 \mathrm{a}$ & $4.4 \pm 0.2 \mathrm{a}$ & $2.8 \pm 0.2 \mathrm{a}$ & $0.3 \pm 0.2 \mathrm{a}$ \\
\hline & Shake flask & $5.7 \pm 1.2 \mathrm{a}$ & $6.4 \pm 0.5 \mathrm{~b}$ & $4.2 \pm 0.8 \mathrm{~b}$ & $1.1 \pm 0.3 \mathrm{~b}$ \\
\hline \multirow{2}{*}{ A.longiloba } & Agar-gelled & $4.5 \pm 0.6 \mathrm{a}$ & $5.2 \pm 0.2 \mathrm{a}$ & $3.1 \pm 0.4 \mathrm{a}$ & $0.7 \pm 0.2 \mathrm{a}$ \\
\hline & Shake flask & $5.8 \pm 0.2 \mathrm{~b}$ & $5.8 \pm 0.7 \mathrm{a}$ & $6.7 \pm 0.3 \mathrm{~b}$ & $1.6 \pm 0.1 \mathrm{~b}$ \\
\hline \multirow{2}{*}{ A.chaii } & Agar-gelled & $4.2 \pm 0.4 \mathrm{a}$ & $6.0 \pm 1.2 \mathrm{a}$ & $5.7 \pm 0.6 \mathrm{~b}$ & $1.8 \pm 0.1 \mathrm{~b}$ \\
\hline & Shake flask & $5.9 \pm 1.0 \mathrm{a}$ & $5.1 \pm 0.2 \mathrm{a}$ & $3.2 \pm 0.2 \mathrm{a}$ & $1.2 \pm 1.0 \mathrm{a}$ \\
\hline
\end{tabular}

Mean values \pm s.d followed by same letter for each parameter of each species are not significantly different at $p \leq 0.05$ [valores médios \pm s.d seguidos por mesma letra na coluna, para cada espécie não são significativamente diferentes pelo teste de Tukey $(p \leq 0,05)]$.

and the lowest number of shoots was produced by $A$. robusta $(3.4 \pm 1.0$ per explant) when they were cultured on MS medium supplemented with $2.0 \mathrm{mg} / \mathrm{L}$ BA. For all the five Alocasia species, only a single shoot was produced from each explant when they were cultured on basal MS medium (without BA) (Table 1). This indicated that the addition of plant growth regulators was essential for the adventitious shoot formation and plant development. When shoots were cultured in lower concentration of BA $(2.0 \mathrm{mg} / \mathrm{L})$ normal and rapid growth was observed. However, higher concentration of BA ( 5 and $10 \mathrm{mg} / \mathrm{L}$ ) induced shoots which were pale and stunted in all the studied species. The 
Table 3. Growth and survival rate of five Alocasia species after four weeks of acclimatization (crescimento e taxa de sobrevivência de cinco espécies Alocasia após quatro semanas de aclimatação). Malaysia, USM, 2010.

\begin{tabular}{lcc}
\hline Species name & Acclimatization $\mathbf{( \% )}$ & Plant height $(\mathbf{c m}) \pm$ s.d \\
\hline A. amazonica & 100 & $9.9 \pm 0.3$ \\
A. cuprea & 92 & $5.7 \pm 0.1$ \\
A. robusta & 92 & $6.7 \pm 0.3$ \\
A. longiloba & 96 & $7.7 \pm 0.3$ \\
A. chaii & 92 & $5.5 \pm 0.3$ \\
\hline
\end{tabular}

concentration of cytokinin clearly influenced the number and morphology of the shoots produced per explant in the tested species. Thao et al. (2003) also reported the occurrence of abnormal shoots among different Alocasia species cultured in higher concentration of BA.

There was also no root formation in the presence of high concentrations of BA. It has been proven that high concentrations of cytokinin generally inhibit the formation of roots in plants (George \& Sherrington, 1984). BA often regulates the activities of the cell such as cell division and expansion, promotes axillary and adventitious shoot bud proliferation and differentiation, and inhibits the formation of roots (Taiz \& Zeiger, 2010). In all the species, roots were only formed in shoots cultured on MS medium supplemented with lower concentration BA and in the absence of BA. However, shoot explants cultured in basal MS medium produced shoots with significantly longer roots in all the species except for A. chaii. For A. chaii, shoots cultured on basal MS medium as well as MS medium supplemented with $2.0 \mathrm{mg} / \mathrm{L}$ BA did not show significant difference in terms of root length. As reported by Thao et al. (2003), rooting of Alocasia species was also achieved in MS medium with and without the addition of lower concentrations of plant growth regulator. For A amazonica, $A$. robusta and $A$. chaii there was no significant difference in shoot height among all the tested concentrations of BA supplemented to the MS medium. However, shoots of $A$. cuprea cultured on MS medium supplemented with 2.0 $\mathrm{mg} / \mathrm{L}$ BA produced significantly higher shoot height as compared to those shoots cultured in other concentrations of BA. For A. longiloba, shoot explants cultured on MS basal medium as well as MS medium supplemented with 2.0 $\mathrm{mg} / \mathrm{L}$ BA produced significantly higher shoot height as compared to shoots cultured in higher concentrations of BA (Table 1). Higher concentrations of cytokinin often lead to a decrease in shoot number and shoot height as reported by Thirugnanasampandan et al. (2010).

All the test species except $A$. chaii cultured in the shake flask system showed significant increase in shoot number as compared to those shoots cultured in agar-gelled medium. There was also significant increase in shoot height for A. amazonica, A. cuprea and $A$. robusta cultured in the shake flask system as compared to agargelled cultures. However, there was no significant difference in shoot height for A. longiloba and A. chaii cultured in both systems. All the species, except $A$. amazonica and $A$. Chaii, showed significant increase in root number in the shake flask system. A. chaii shoots cultured on agar-gelled medium performed better in terms of root number. Root length was also significantly longer for all species cultured in liquid medium except for $A$. chaii and A. cuprea. (Table 2). Similar observation was made by Kadota \& Niimi (2004) for Japanese yam, whereby liquid medium was superior to solid medium in terms of shoot and root production. Their results showed three times increase in shoot and root production in yam shoot explants cultured on liquid medium as compared to those cultured on solid medium. The advantages of liquid cultures for enhancing shoot proliferation and growth has been reported for other species such as garlic (Kim et al., 2003) and Zingiber officinale (Adaniya
\& Shirai, 2001). Kim et al. (2003) hypothesized that higher shoot growth in liquid medium was due to the fact that a larger surface area of explant tissue was exposed to the liquid medium. They observed a two fold increase in fresh weight of the garlic shoots cultured in liquid medium as compared to solid medium. Adaniya \& Shirai (2001) explained that increased shoot development in liquid medium indicated that large number of cells in the shoot apices were undergoing mitosis. Among the five species, A. amazonica and $A$. cuprea showed the highest shoot proliferation $(8.2 \pm 0.2 b \& 8.7 \pm 1.2 b)$ when cultured in liquid medium as compared to other species. Similar observation was reported by Sedlak \& Paprstein (2008) in sweet cherry. They reported that different sweet cherry genotypes produced varying results in terms of shoot proliferation. They explained that difference in shoot multiplication could be due to the interaction of various auxins and cytokinins present in the tissues during metabolism. Different species of Alocasia produced different in vitro responses in terms of shoot production, shoot height and root production. Thao et al. (2003) reported that shoot quality and shoot production in Alocasia species was also affected by the genotype, type and concentrations of cytokinins. The difference in the shoot production and shoot height was also reported in different genotypes of rose (Carelli \& Echeverrigaray, 2002).

After 4 weeks of acclimatization, all five species showed vigorous growth with a survival rate of more than $90 \%$. This indicated that our proposed protocol of acclimatization was suitable for the five Alocasia species. However, the plantlets growth rate based on their height was found to be different among the five species (Table 3 ). All the in vitro plantlets were normal and healthy after transferred to the soil (Figure 1B).

The present study concludes that the MS medium supplemented with $2.0 \mathrm{mg} / \mathrm{L}$ BA was optimum for shoot proliferation in all tested species of Alocasia. Liquid media has several advantages over the agar-gelled medium. The elimination of gelling agent in liquid medium further 
reduces cost of plantlets production. The present micropropagation protocol can hence be used as a cost effective method for commercial production of Alocasia species and also as a tool for germplasm conservation.

\section{ACKNOWLEDGEMENTS}

Arvind Bhatt thanks Universiti Sains Malaysia for Post-Doctoral Fellowship and School of Biological Sciences, Universiti Sains Malaysia for providing the research facilities. Christine Stanly would like to thank Universiti Sains Malaysia for USM fellowship for the present study. The authors are also thankful to Prof Ashley Nichloas for improving the English of the manuscript.

\section{REFERENCES}

ADANIYA S; SHIRAI D. 2001. In vitro induction of tetraploid ginger (Zingiber officinale Roscoe) and its pollen fertility and germinability. Scientia Horticulturae 88 :
277-287.

ADELBERG J; TOLER J. 2004. Comparison of agar and thin-film liquid system for micropropagation of ornamental Alocasia and Colocasia. HortScience 39: 1088-1092.

BOYCE PC. 2008. A review of Alocasia (Araceae: Colocasieae) for Thailand including a novel species and new species records from SouthWest Thailand. Thai Forest Bulletin (Botany) 36: 1-17.

BOYCE PC; SULAIMAN B; LINTONG J. 2002. Araceae of the Crocker Range National Park Sabah: A premiliminary survey, checklist and generic key. ASEAN Review of Biodiversity and Environmental Conservation (ARBEC). Available in http://www.arbec.com.my/pdf art4julysep02.pdf. Accessed in June 25, 2010.

CHAN LK; CHONG YT. 2010. Establishment of a rapid in vitro propagation system for Alocasia longiloba Miq. Watsoniana. Propagation of Ornamental Plants 10: 24-28.

GEORGE EF; SHERRINGTON PD. 1984. Plant propagation by tissue culture: Handbook and Directory of Commercial Laboratories. London: Exegetics Ltd. p102-110.

IUCN. 2010, JUNE 25. IUCN red list of threatened species. Available in www.iucnredlist.org.

JO EA; TEWARI RK; HAHN EJ; PAEK KY. 2008. Effect of photoperiod and light intensity on in vitro propagation of Alocasia amazonica. Plant Biotechnology Reports 2: 207-212.

KADOTA M; NIIMI Y. 2004. Improvement of micropropagation of Japanese yam using liquid and gelled medium culture. Scientia Horticulturae 102: 461-466.

KIM EK; HAHN EJ; MURTHY HN; PAEK KY. 2003. High frequency of shoot multiplication and bulblet formation of garlic in liquid cultures. Plant Cell, Tissue and Organ Culture 73: 231-236.

MURASHIGE T; SKOOG F. 1962. A revised medium for rapid growth and bioassays with tobacco tissue cultures. Physiologia Plantarum 15: 473-497.

SANATOMBI K; SHARMA GJ. 2008. In vitro plant regeneration of six cultivars of Capsicum spp. using different explants. Biologia Plantarum 52: 140-145.

SEDLAK J; PAPRSTEIN F. 2008. In vitro shoot proliferation of sweet cherry cultivars Karesova and Rivan. Horticultural Science 35: 95-98.

TAIZ L; ZEIGER E. 2010. Plant physiology (Fifth edition). Sinauer Associates, Sunderland, Massachusetts. 452-453p.

THAO NTP; MIYAJIMA I; URESHINO K; OZAK Y; OKUBO H. 2003. Micropropagation of Ornamental Alocasia. Journal of Faculty of Agriculture Kyushu University 47: 277-282.

T H I R U G N A N A S A M PA N D A N R; MAHENDRAN G; NARMATABHAI V. 2010. High frequency in vitro propagation of Isodon wightii (Bentham) H. Hara. Acta Physiologia Plantarum 32: 405-409. 